This is an Accepted Manuscript of an article published by Taylor \& Francis in British Journal of Sociology of Education on August 8 2014, available online:

http://www.tandfonline.com/10.1080/01425692.2014.933668

Please cite as :

Laplante, Benoît, Pierre Doray, Nicolas Bastien, and Pierre Chenard. 2016. "A tale of two logics: social reproduction and mobilisation in university access in Quebec, 1945-2000." British Journal of Sociology of Education 37 (2):313-333. doi: 10.1080/01425692.2014.933668. 


\title{
A tale of two logics: social reproduction and mobilisation in university access in Quebec, 1945-2000
}

\author{
Benoît Laplante \\ Centre Urbanisation Culture Société \\ Institut national de la recherche scientifique \\ Montréal, Québec, Canada \\ Pierre Doray \\ Département de sociologie \\ Université du Québec à Montréal \\ Montréal, Québec, Canada \\ Nicolas Bastien \\ Centre interuniversitaire de recherche sur la science et la technologie \\ Université du Québec à Montréal \\ Montréal, Québec, Canada \\ Pierre Chenard \\ Faculté des sciences de l'éducation \\ Université de Montréal \\ Montreal, Quebec, Canada
}

\begin{abstract}
The 2012 Quebec students' protests against university tuition fees fostered a debate on access to higher education in Quebec, and specifically on the Quebec 'educational lag'. Using census data, we show that degree-holding is the same among Quebec French-speaking and Ontario English-speaking populations. Using event history analysis, we show that, during the second half of the twentieth century, university access increased at a different rhythm in each province and, within each province, within socio-linguistic groups. Quebec current education policy should not focus on the 'educational lag', which past policies have helped make up for, but on inequality in university access.
\end{abstract}

\section{Keywords}

Quebec (province); social reproduction; cultural capital; educational mobility; educational trends; immigration

This is a postprint version. Please cite the published article:

Benoît Laplante, Pierre Doray, Nicolas Bastien and Pierre Chenard. "A tale of two logics: social reproduction and mobilisation in university access in Quebec, 1945-2000”. British Journal of Sociology of Education 37(2): 313-333. doi: 10.1080/01425692.2014.933668. 


\section{Introduction}

In early 2012, Quebec students massively mobilised against the provincial government imposition of a $75 \%$ university tuition fee increase. The pressure led the Premier to announce an early general election in September. The governing Quebec Liberal Party was defeated and replaced by the Parti Québécois, which revoked the increase and, in February 2013, held a series of public hearings on higher education. These focused on the issues raised by the student movement: tuition fees, accessibility, retention and persistence, quality of higher education, as well as university funding, governance and accountability.

The conflict and the hearings revived discussions on a common preconception about education in Quebec, the so-called 'educational lag', as well as on the effects of social origin and fees on university attendance. Some stressed that Quebec was still 'lagging' behind neighbouring Ontario because, after decades of reform, the proportion of the adult population that holds a university degree is still less in Quebec than in Ontario. Others reiterated that fees have no effect on attendance, using Ontario as evidence, where tuition fees have been much higher than in Quebec for several years but where the proportion of degree-holders is higher.

One cannot determine whether the adult population of Quebec is currently less educated than that of Ontario solely by comparing raw percentages. Some people attend university outside the province in which they reside, while others leave the province in which they were born and educated. Internal migration blurs the relation between the proportion of university degree-holders in a province and that province's education policy and education system. In Canada, however, immigration is a more important factor. Canadian immigration policy favours university graduates. Consequently, many degree-holding Canadians never attended university in Canada. Furthermore, research shows that children of immigrant families are strongly encouraged by their parents to attend university. Thus, the proportion of the population of a province that holds a university degree depends, in part, on the selection policy of immigrants and on social reproduction among immigrants. In Ontario, where more than one-quarter of the population is foreign-born, the proportion of degree-holders depends to a large extent on immigration, more than in Quebec where the proportion of the foreign-born population is lower. In both provinces, tuition fees, as well as the proportion of youth cohorts attending university, have increased over the years, making it very difficult to estimate the effect of tuition fees on enrolment. In addition, attendance varies according to social origin, and the effect of tuition may vary according to social origin. Because of the composition of its population, it is likely that tuition fees play a greater role in Quebec than in Ontario. 
The 'educational lag', the extent of immigration and the effect of tuition fees on enrolment constitute an intricate set of questions. Depending on the answers, research will support one of several competing views on the appropriate higher education policy goal and measures. If the Quebec Frenchspeaking majority is truly less educated than the Ontario English-speaking majority, the longstanding policy of favouring university enrolment through public funding and low fees will be deemed a failure and pressure will grow to increase fees. If the Quebec French-speaking majority is as educated as the Ontario English-speaking majority but is still less educated than the Quebec English-speaking minority, the 'lag' between the two provinces will become a 'gap' between groups defined by class and language. Public funding and low fees will have succeeded in putting the Quebec French-speaking majority on a par with the Ontario English-speaking majority, and the remaining difference between French-speakers and English-speakers within Quebec will be a direct consequence of the concentration of the Englishspeaking population within the upper class.

From a theoretical perspective, looking into the current Quebec political debate over postsecondary education involves studying a case in which the logic of social reproduction combines with that of mobilisation. The current situation emerged over a period in which elites increased their investment in their children's education, and social groups, notably women and French- speaking Quebeckers, mobilised to access postsecondary education. The current debate, which is basically about public funding of university education, highlights recent changes in some groups' strategies.

Similar differences and debates occur in other countries where education is not controlled by the central government. The example of Scotland not raising tuition fees when England does immediately comes to mind. Members of the European Union have different policies on these matters. Our approach - longitudinal, biographical, generational and comparative - could be of interest for research on comparative education policies. In particular, it could be used in countries where the Gender and Generation Program surveys are conducted. We provide an overview of our two key concepts, social reproduction and mobilisation, as well as some background on higher education and its transformation over the second half of the twentieth century in Quebec and Ontario. We look at the evolution of enrolment and the enrolment rate, and at the current proportion of the Ontario and Quebec population holding a university degree. Unlike most studies, we examine this proportion within selected social groups to highlight the relation between degree-holding and social structure in each province. In our core analysis, we focus on the evolution, across cohorts, of the effects of social origin on enrolment within a selection of social groups in Ontario and Quebec. 


\section{The two logics: reproduction and mobilisation in higher education}

The role of education in social reproduction is closely associated with the work of Bourdieu. From one generation to the next, individuals tend to end up in social positions equivalent to that of their parents. This transmission process is linked to the unequal distribution of family cultural, social and economic capital (Bourdieu 1984, 1990). Reproduction strategies change over time. Some fractions of the dominant classes have added schooling to their repertoire of reproductive strategies, thereby adding the conversion of economic capital into educational capital to the traditional use of networks and transmission of the economic capital itself (Bourdieu, Boltanski, and Saint-Martin 1973; Bourdieu 1998). As a consequence of this strategic use of education, schooling paths vary across classes or fractions of classes (Willis 1979; Reay 1998; Smyth and Bank 2012).

Research on the role of education in social reproduction focused first on social classes, but was extended to consider its role in the perpetuation of other dimensions of the social hierarchy, especially gender and ethnicity. Women's studies pointed out that the enrolment of women in postsecondary education, until recently lower than that of men, was an aspect of the domi- nation to which they were subject (Descarries 1980; Arnot and Weiner 1987; Dumais 2002). In the USA, studies focused on the limited access of African-Americans and Latinos to higher education; and in France, they focused on the limited access of those of North African descent. In Quebec, where the French-speaking majority still attends university less than the English-speaking minority and where gender relations have been and are still changing, making sense of the role of education in social reproduction requires consideration of class, gender and ethnicity (Dandurand, Fournier, and Bernier 1980; Dandurand 1986, 1991).

Social reproduction explains how education is used by actors from higher positions to maintain and transmit their position, but not why or how enrolment in higher education has increased across classes, gender and ethnic groups since the beginning of the twentieth century. Bowles and Gintis (1976) view this increase as a consequence of a change in the needs of capitalistic production. Bourdieu (1974) interprets the increase as a form of inflation caused by the determination of the upper classes to maintain their distance from the other classes once they start investing in education. These interpretations are worthwhile, but fall short of explaining why, at some point, actors from lower social positions have increased aspirations for higher education (Clark 1960; Bélanger 1986).

Such changes in aspiration have been interpreted as instances of mobilisation; that is, investment in schooling by actors from lower social strata either to move across positions or as a means of reducing across-group inequality. Mobilisation for better schooling and increased access to higher education may 
be a form of collective or political action, much like the Langevin-Wallon Plan in France in the late 1940s, the American civil rights movement in the1960s, Quebec's education reform of the late 1960s and early 1970s, and women's struggle for equal access to higher education during much of the twentieth century. The mobilisation for education in France and in Quebec led to the expansion of the education system to accommodate the growing number of students. Mobilisation may also be a strategy favoured by families from some groups, but in an individualistic fashion. This may be the case for immigrants who invest heavily in their children's education as a means of positioning them in the upper class of their new country (Terrail 1990; Lahire 1998, 2002; Zéroulou 1988).

\section{Higher education and society in Quebec and Ontario}

Canada is a federation, and education falls under provincial jurisdiction. Each province has its own education system and policies, and these have changed over time in different ways and at a different pace.

In 1945 the Ontario postsecondary landscape consisted of three universities, several private colleges, and a few institutes specialised in technical or professional training. The expansion of the economy during the post-war period created a high demand for skilled labour and, in the late 1950s evidence of the public need and desire for the expansion of higher education was coming from all directions (Jones 1997). Starting in the 1960s, the provincial government established several new universities. By 1963 Ontario had 14 universities and undergraduate enrolment reached 35,000 (Monahan 2004; Clark et al. 2009).

In 1965 the Government of Ontario established a province-wide network of non-university postsecondary education institutions, the Colleges of Applied Arts and Technology (CAAT). The CAAT were designed as a distinct postsecondary education system clearly separated from universities. They provide a wide range of technical and vocational training programmes and they support apprenticeship programmes (Jones 1997). Nineteen CAAT were operating by 1967. In 1970, these colleges enrolled more than 35,000 students in full-time programmes (Vision 2000 Steering Committee 1990).

From 1944 to 1960 Quebec was led by a conservative government that resisted the kind of modernisation in education and, more generally, in public administration that was occurring at that time in much of the western world. By the end of the 1950s, the Quebec postsecondary education landscape was similar to that of Ontario in 1945. However, the Liberal government elected in 1960 promoted change. It set up a royal commission to investigate education in the province. The commission advocated 
a complete reform of the education system. Most of the commission's recommendations were implemented before the end of the 1960s.

The reform aimed at the social, geographical and demographic democratisation of education, as well as modernisation of the curriculum, and was supported by the French-speaking elite (Bélanger, Comeau, and Métivier 2000). Some of its main features were the establishment of a Ministry of Education and the setting up of a four-level education system: primary, secondary, college and university. They also included the foundation of the Université du Québec, a provincial network of public universities modelled on the University of California, and the creation of a network of colleges providing pre-university as well as vocational education ('collèges d'enseignement général et professionnel' [CEGEP]). Currently, there are 13 French-language universities, three English-language universities, 48 public CEGEP providing pre-university and vocational education, and about 30 private colleges.

\section{University enrolment in Quebec and Ontario}

In Quebec, since the beginning of the reforms in the 1960s, enrolment in French-language universities has increased almost 10-fold (Figure 1). Growth was strong and steady from 1966 to 1992, but enrolment decreased from 1993 to 1998. Growth resumed thereafter, and by 2006 enrolment was back to its 1992 level. The growth was made possible by the founding of the Université du Québec and by increasing capacity in the established universities. The decrease in enrolment between 1993 and 1998 came after an increase in tuition fees, but also at a time when the last baby-boomers were moving out of the age range in which most people attend university. Other research shows that the decrease in enrolment in the mid-1990s was stronger among part-time students and students aged at least 25 (Chenard and Doray 2013). The increasing enrolment from the mid-1960s until the beginning of the 1990s may be described as catching up.

In the 1990s, enrolment in English-language universities did not decrease as much as that in Frenchlanguage universities. The growth in enrolment in Quebec English-language universities closely follows that of Ontario universities until the beginning of the 2000s. There are several possible causes for the relatively stable enrolment levels in Quebec English-language universities in the 1990s. In Quebec, on average, English-speaking families are more affluent than French-speaking ones and students from wealthier families may be little affected by changes in tuition. Attending McGill University has long been

a distinction strategy among French-speaking elite families (Dandurand, Fournier, and Bernier 1980). 
English-language universities welcome a large number of students from outside Quebec or Canada whose presence may offset decreasing enrolment by Quebec students, if necessary. More generally, however, it seems that until the beginning of the 2000s enrolment in Quebec English-language universities followed the pat- tern of enrolment in Ontario universities, as if English-speaking Quebec and Ontario were part of a single society. Figure 1 suggests that the recent difference in enrolment growth between Ontario universities and Quebec English-language universities reflects a difference in the growth of the youth population in Ontario and Quebec.

Figure 2 displays the evolution, over time, of the ratio of university enrolment to the size of the population aged 18-29 in Quebec and Ontario. Between 1966 and 1983, the ratio increased from 4.7\% to $13.8 \%$ in Que- bec; in Ontario, it rose from $12.0 \%$ to $13.8 \%$ (sic) between 1972 and 1983 . Since then, it has been higher in Quebec than in Ontario. The difference between these provinces increased from 1983 until the mid-1990s, when enrolment diminished in Quebec. The difference has been decreasing since the late 1990s and, since the mid-2000s, the ratio has been about the same in the two provinces. Overall, Quebec had made up for its lag by 1983, and has been a leader ever since. Ontario 'lagged' behind Quebec until the late 1990s.

\section{Degree-holding in Quebec and Ontario}

The proportion of the adult population holding a university degree is the most common measure used to argue that the Quebec educational lag still exists, and that the education reform and education policy have been a failure.

In Tables 1, 2 and 3 we use data from the 2001 Census of Canada to look at the evolution of degree-holding in Quebec and Ontario across 10-year birth cohorts. Table 1 presents the proportions of degree-holders by mother tongue for the entire resident population. Overall, French-speaking Quebeckers have the lowest proportion of degree-holders. This is true even for the youngest cohort, which should have fully benefited from the reform implemented in the 1960s. Such figures are routinely interpreted as a strong indication that the Quebec education policy has failed, and that the main education policy issue remains the 'educational lag' (for example, Centre for Productivity and Prosperity 2012; D’Amours 2010; Perreault 2012a, 2012b).

Such a comparison is misleading because it ignores the differences in social composition between Quebec and Ontario. In Quebec, French-speakers are the majority. They form a complete social hierarchy, with people spread across social classes, as in most contemporary western societies, with few 
in the upper class and more in the middle and lower classes. However, the English-speaking minority is more concentrated towards the top of the social pyramid. In Ontario, English-speakers are the majority and they form a complete social hierarchy, whereas the French-speaking minority is more concentrated towards the bottom of the social pyramid. In both provinces, as in Canada as a whole, the immigration flux is substantial, but it is greater in Ontario than in Quebec. According to the 2006 Census, 28.3\% of the Ontario population is foreign-born, compared with 11.5\% in Quebec. Although some immigrants are children accompanying their parents and will be educated in Canada, the proportion of people holding a degree in a province is a function of the proportion of its population that is foreign-born. Furthermore, research consistently reports that Canadian immigrants strongly encourage their children to obtain a university education (Chiswick and DebBurman 2004; Bonikowska and Hou 2010; Finnie and Mueller 2010).

Table 2 presents the proportions of what may be called the 'historical populations' of Quebec and Ontario; that is, individuals with two parents born in Canada and living in the province where they were born (Laplante, Sabourin, and Bélanger 2010). Table 2 offers a different picture from that of Table 1. The proportion of degree-holders is lower among the Quebec French-speaking population than among the Ontario English-speaking population in the three oldest cohorts. However, the proportions are close in the fourth cohort (15.2\% and 15.7\%). They are almost exactly the same in the most recent cohort $(21.0 \%$ and $21.2 \%)$. The proportion is higher among the Quebec English-speaking group than among the Quebec French-speaking group in all cohorts; it is also higher among Quebec English-speakers than among Ontario English-speakers from the third cohort onwards. Quebec education policy and reform have apparently succeeded in increasing the proportion of degree-holders among Quebec Frenchspeakers to the level of Ontario English- speakers, the only group with which comparison is reasonable. Raising it to the level of Quebec English-speakers could only be achieved by eliminating social stratification, which can hardly be a realistic policy objective.

Table 3 presents the proportion of degree-holders among people born out- side Canada ("foreignborn') and among people born in Canada from two parents born outside Canada ('two parents'). There is no reason to believe that the Quebec and Ontario English-speaking 'historical' populations have experienced the democratisation of higher education later than other industrialised or advanced western societies. However, the proportion of degree-holders among immigrants and their children, even in the older cohorts, is higher than among each and every group of the 'historical' populations and is very high 
by any conceivable standard. This feature is not a consequence of education policy, but of immigration policy and, probably, of social reproduction through family and individual investment in education.

\section{Hypothesis, data and methodology}

\section{Hypothesis}

Aggregate data on enrolment show no evidence that the Quebec education system impedes access to university. On the contrary, the data show that the 'educational lag' may have been rectified as early as the mid-1980s. Cross-sectional census data show that, in the most recent cohorts, the proportion of degreeholders is the same among the Quebec French-speakers and Ontario English-speakers. The still significant gap between Quebec French-speakers and Quebec English-speakers is probably a consequence of the relative concentration of Quebec English-speakers in the upper class and the workings of social reproduction. The larger gap between Quebec French-speakers and immigrants and their children is probably a by-product of immigration policy and social reproduction.

We are interested in modelling access to university as a process at the individual level, in order to estimate the net effect of social origin, and thus the role of social reproduction, and its change over time in Quebec and Ontario within groups defined by language and origin. Our objective is to compare the strength of the effects of social reproduction across groups, and assess whether this strength, within each group, has been constant across cohorts or has been increasing. Difference across groups in the strength of social reproduction and increase in the strength of social reproduction across cohorts would signal that the main issue, for education pol- icy, should be counterbalancing social reproduction.

\section{Data}

We use data from the General Social Survey, a survey of the population aged 15 years and older carried out yearly by Statistics Canada. In 1995, 2001, 2006 and 2011, as part of a biographical survey of familyrelated events, the survey collected the age upon completion of studies. Taken together, the data from these four surveys comprise a sizeable probabilistic sample of Canadians who reached the customary age of enrolment in university between the immediate post-war period and the beginning of the new millennium.

\section{Method}

We use an event history analysis approach and focus on the age at enrolment, employing two statistical models. The Kaplan-Meier estimator of the survivor function estimates the proportion of the 
population still in the state of origin at any given time. This allows us to estimate and compare across groups the proportion of those who have enrolled in university at any given age and the total proportion of each group that will have enrolled by age 50. The second model, the semi-parametric Cox proportional hazards model, is closely related to the first. It allows us to estimate the effect of selected characteristics, such as birth cohort or parental education, on the probability of enrolment in university at any given age. (See Box-Steffensmeier and Jones [2004] for an introduction to these models). The models are estimated using delayed entry to exclude the portion of immigrants' biographies before their landing in Canada. The estimates are weighted and standard errors are adjusted using an estimate of the average design effect (Kish 1995).

\section{Variables}

The birth cohorts are defined to capture changes in demography and social and economic context, as well as in education policies and systems. The first cohort, 'before 1936', is comprised of those born before the beginning of the baby boom in Canada; the second, '1936-1950', comprises roughly the first half of the baby boomers; the third, '1951-1974', comprises the second half of the baby boomers; and the fourth, '1975-1990', is comprised of people born after the baby boom. People from the first and second cohorts reached age 18 in very different social and economic circumstances, but in Quebec both did so before the creation of CEGEP and the founding of the new universities, at the end of the 1960s. The last two cohorts also reached age 18 in different social and economic circumstances, but at a time when the new educational offering was operational.

The socio-linguistic groups are defined by combining information on the birthplace of respondents, their parents' birthplace, their first language and, for immigrants, their age at immigration.

Social origin refers to the education level of respondents' parents. We use three modalities: 'no postsecondary education', neither father nor mother has more than a secondary diploma; 'non-university postsecondary education', father or mother has a postsecondary diploma, but neither has a university diploma; and 'university', father, mother or both have a university diploma.

In most cases, age at first enrolment in university had to be assessed indirectly using the age at completion of studies and the highest degree ever obtained rather than the age at first enrolment. We resorted to the solution commonly used in such cases, determining the age at first enrolment backwards from the age at completion of studies. Unfortunately, these are the best data available in Canada. 


\section{Results}

Figure 3 displays the cumulative probability over age by birth cohort of having ever attended university for people belonging to six socio-linguistic groups.

The final cumulative probability of enrolment increased from the oldest to the youngest cohort in the two major socio-linguistic groups. Among the Quebec French-speaking population, it reached about $30 \%$ in the youngest cohort, and was somewhat higher among the Ontario English-speaking youngest cohort. Among the Quebec French-speaking population, the increase has been progressive from the oldest to the youngest cohort. Among the Ontario English-speaking population, the increase has been a two-stage process, and there is little difference between the second and third cohorts. The pattern of increase among Quebec English-speaking people is pretty similar to the pattern seen among the Quebec French-speaking people, although the final cumulative probability is higher among the former in all cohorts but the oldest. The pattern of increase among the Ontario French-speaking population is different. There is little progress from the first to the second cohorts, and a strong increase in the third cohort, where first enrolment in university is spread almost evenly throughout the population in their 20s. There is a second marked increase from the third cohort to the youngest, with much of the enrolment concentrated just before age 20. The final cumulative probability of the youngest Ontario French-speaking cohort remains somewhat lower than those of the other groups. The pattern of increase among Quebec and Ontario immigrants is quite similar. The final cumulative probability is higher among those groups than in any other. The progress is constant from the oldest to the youngest cohorts. The final cumulative probability of the youngest cohort is about $50 \%$ in both cases.

Table 4 reports the estimates of the effects of these factors on the hazard rate of enrolling in university. We report gross and net effects. Comparing gross and net effects sometimes provides valuable information about the structure of the relations between independent variables and the dependent variable (Aneshensel 2002).

Among the Quebec French-speaking population, the gross effects of both the birth cohort and social origin are significant. The coefficients associated with the birth cohorts basically reflect the differences depicted in Figure 3. The coefficients associated with social origin indicate that having parents with postsecondary education dramatically increases the probability of ever attending university. The net effects tell a different story. Social origin remains strongly associated with enrolment, but most of the association between birth cohort and enrolment disappears. According to these results, the increase in the rate of enrolment from the oldest cohort to the second cohort is probably associated 
with some change in education policies or sys- tem, but most, if not all, of the observed increase from the second to the third cohorts and from the third to the fourth cohorts is due to social reproduction. A significant proportion of people born before 1936 who enrolled did not have parents with postsecondary education, but most of those from younger generations who enrolled had parents with some level of postsecondary education.

The results are somewhat similar among Quebec English-speaking people, but with some differences. In Figure 3 the distance between the curve of the oldest cohort and the second cohort is large, but the distances between the three youngest cohorts are relatively small. The gross coefficients associated with the birth cohort reflect these differences: the progress in enrolment has been huge from the oldest cohort to the second, but smaller thereafter. As among the Quebec French-speaking population, the effect of social origin is important. The net effects tell a story similar to that we saw among the Quebec French-speaking population, although the impact of social origin is smaller among the Quebec English-speaking than among the Quebec French-speaking.

In the Quebec immigration group, the net effects of the birth cohort show a major increase from the oldest to the second cohorts, and a large decrease from the third cohort to the youngest. The effect of social origin is similar to what is found among the Quebec French-speaking and Quebec Englishspeaking populations. In the Quebec immigration group, the net effects show that having two parents born abroad increases the probability of enrolment. The disappearance of the effect of having arrived before age 15 once that of social origin is controlled is probably a consequence of the selection of adult immigrants who are university graduates.

Among the Ontario English-speaking population, the gross effects show a large increase in the probability of enrolment from the oldest to the second cohorts and from the third to the youngest cohorts, as well as a strong effect of social origin. The net effect suggests a slightly different story. Once social origin is controlled, the second cohort has a hazard function similar to that of the most recent, whereas the third cohort falls in between the second and the most recent cohorts. Apparently, some external factor, probably related to education policy or the education system, decreased the enrolment hazard rate and the observed stability of the cumulative probability function was actually achieved through the effect of social reproduction.

Among the Ontario French-speaking population, the gross effects of birth cohort reflect the distances as they appear in Figure 3. Again, the gross coefficients indicate a large effect of social origin. 
The net effects suggest that the increase in enrolment from the second to the third cohorts has to do with some external cause, but that the more recent increase is basically driven by social reproduction.

Likelihood ratio tests show that, for the Ontario immigration group, the effect of social origin has changed over birth cohorts. In this group, the within-cohort relative effect of having a parent holding a university degree compared with not having a parent with some postsecondary education is greatest in the oldest cohort $(1.149 / 0.171=6.72)$, decreases sharply from the oldest to the second cohorts $(1.632 / 0.429=3.80)$, is about the same in the second cohort as in the third cohort $(1.950 / 0.525=3.71)$, and is smallest in the youngest cohort $(2.331 / 1=2.33)$. The effect of integration into Canadian society is similar to its effect in the Quebec immigration group, although somewhat smaller.

\section{Discussion}

Cohort analysis of the socio-linguistic majority groups of Ontario and Quebec shows that during the second half of the twentieth century, the cumulative probability of undertaking university studies increased markedly from less than $8 \%$ to more than $30 \%$. In the two most recent cohorts (i.e. among those reaching the normal age of entry into university from the late 1960s onwards), the probability of access is almost equivalent in the two groups. The change in Ontario differed slightly from that in Quebec. In Ontario, the increase occurred in two stages; in Quebec, it was a three-step process, more gradual and delayed. The increased probability of access between the second and third cohorts corresponds to the implementation of the reforms beginning in the 1960s that dramatically transformed the education system. These reforms were intended to encourage Quebeckers to stay in school longer and especially to go to university. They achieved their goals.

The probability of entering university has evolved differently in the two provinces' minority groups. It grew faster among Quebec English-speakers than among Ontario French-speakers. In the most recent cohort, the cumulative probability is still higher among Quebec English-speakers than among Ontario French-speakers. The difference lies in the socio-economic composition of the two groups, their spatial distribution and the availability of university education. Quebec English-speakers are concentrated in the upper class, most live in and around Montreal, and there are three English- language universities in Quebec. Few Ontario French-speakers are in the upper class and many of them live in parts of the province where there is little postsecondary education offered in French (Commissariat aux services en français 2012). 
The results also show that the increasing probability of access to university is not solely the direct result of policy: social reproduction, most noticeable in the effect of parents' educational capital, is instrumental in all groups. This effect seems greater in Ontario than in Quebec. Its strength is constant across all groups, except for Ontario immigrants, for whom it increases from the oldest cohort to the most recent.

\section{Conclusion}

Our core empirical finding is that, in more recent cohorts, the proportion of Quebec French-speakers attending university is almost the same as that of Ontario English-speakers. This finding has several implications. First, Quebec education policy and reform must have had some impact on this result. At the very least, they were responsible for the increased availability of education and, in particular, the increased provision of university education. The mobilisation of French-speakers provided results. Second, the proportion of recent cohorts undertaking university studies being roughly the same in majority groups in Quebec and Ontario suggests that the Quebec education system and education policy have no adverse effects on Quebeckers. Third, this leads us to conclude that the current education issue in Quebec is not the 'lag', and that there is no longer a need for education policy to compensate for that 'lag'. The difference that remains between French and English Quebec is not a 'lag', but a 'gap', the consequence of a difference in social composition. The proportion of French-speaking Quebeckers who hold a university degree is lower than that of English-speaking Quebeckers because the French-speaking majority has a conventional social structure, the upper class being smaller in size than the middle and lower classes, whereas English-speakers are concentrated in the upper class. Many of the most common preconceptions about education policy and reform in Quebec cannot withstand such findings. A successful education policy may increase the proportion of degree-holders in all classes and help people move up across classes, as it did in Quebec, but it cannot counteract all the effects of social reproduction and lead to all classes having the same proportion of degree-holders. Quebec education policy has eliminated the 'lag' between the Quebec French-speaking majority and the Ontario English-speaking majority, but no education policy can close the 'gap' between the Quebec French-speaking majority and English-speaking minority. Practically, this would come close to abolishing the class structure. No form of mobilisation may achieve such a task.

From the standpoint of public policy, social reproduction works in a paradoxical way. Reproduction maintains inequalities that policy is usually intended to reduce but, as one may read between the lines in 
the results, parents' educational capital increases over cohorts and this is a result of past policy. Reproduction looks like an element of a 'virtuous' circle that will persist as long as university education remains an asset that can easily multiply and the policies that made upward mobility through education possible in the past do not disappear.

Our results also show that in Quebec and Ontario, and probably across all of Canada, access to university education is still largely determined by each province's social relations. The relationships between language groups do not change (Dandurand, Fournier, and Bernier 1980; Dandurand 1986, 1991), and class relationships remain significant, especially in the composition of initial cultural capital. In Ontario, French-speakers are disadvantaged, whereas in Quebec, the English-speaking are advantaged. On the other hand, the current situation of Quebec French-speakers is similar to that of Ontario English-speakers.

The most important educational inequality in Quebec today is that which reduces the probability of access to university for children whose parents have no post-secondary education. The February 2013 public hearings on higher education focused on tuition fees, university funding, governance and accountability. Tuition fees were relevant for students because many among them are afraid of the consequences of high tuition fees and debt accumulation. They were relevant also because many among them believe that high tuition fees deter disadvantaged youth from attending university. The 2012 student movement was concentrated in French-language pre-university colleges and universities. The participation was weak, sometimes close to non-existent, in English-language colleges and universities. Some of our results help us to understand why: the proportion of youth whose parents do not have the educational capital that allows them to rely on family investment to undertake university studies is much higher among French-speakers than among English-speakers. Quebec English-speakers are socially favoured and are probably not deterred by high tuition fees. The movement was more important among French-speakers because a large pro- portion of them belong to the lower and middle classes for whom enrolling in university is still a pathway to intergenerational mobility rather than social reproduction, and maybe, for some of the middle class, a threatened means of social reproduction.

In the current situation, mobilisation and social reproduction do not com- bine the way they did before the reforms of the 1960s. Back then, at the time it started using university education as a means of maintaining its social position on a large scale, the Quebec French-speaking elite sided with the rest of the French-speaking society in demanding affordable university education. For a while, among French-speakers, getting a university education was typically something new that parents did not have 
and, thus, was a tool for social reproduction, as well as for social mobility. Today, the French-speaking upper class sides with English-speakers, largely concentrated in the upper class, and with immigrants, a large proportion of them highly educated, and supports the restriction of university education to a means of social reproduction.

\section{References}

Aneshensel, Carol S. 2002. Theory-based Data Analysis for the Social Sciences. Thousand Oaks, CA: Pine Forge Press.

Arnot, Madeleine and Gaby Weiner, eds. 1987. Gender and the Politics of Schooling. London: Hutchinson. Bélanger, Pierre. 1986. "La réponse du Québec aux problèmes d’équité et d'excellence dans l'enseignement post-secondaire [Quebec's Answer to Equity and Excellence Problems in Postsecondary Education]”. Recherches sociographiques 27(3): 365-384.

Bélanger, Yves, Robert Comeau and Céline Métivier, eds. 2000. La révolution tranquille 40 ans plus tard. Un bilan [The Quiet Revolution 40 Years Later: An Assessment]. Montreal: Éditions VLB.

Bonikowska, Aneta and Feng Hou. 2010. "Reversal of Fortunes or Continued Success? Cohort Differences in Education and Earnings of Childhood Immigrants". International Migration Review 44(2): 320-353.

Bourdieu, Pierre. 1974. "Avenir de classes et causalité du probable [Classes Future and Causality of the Probable]." Revue française de sociologie 15(1): 3-42.

Bourdieu, Pierre. 1984. Distinction: A Social Critique of the Judgment of Taste. London: Routledge and Kegan Paul.

Bourdieu, Pierre. 1990. The Logic of Practice. Cambridge: Polity Press.

Bourdieu, Pierre. 1998. State Nobility: Elite Schools in the Field of Power. Cambridge: Polity Press.

Bourdieu, Pierre, Luc Boltanski, Monique de Saint-Martin. 1973. “Les stratégies de reconversion. Les classes sociales et le système d'enseignement [Conversion Strategies: Social Classes and the Education System]". Informations sur les sciences sociales 12(5): 61-113.

Bowles, Samuel and Herbert Gintis. 1976. Schooling in Capitalist America. New York: Basic Books, Harper Colophon Books. 
Box-Steffensmeier, Janet M. and Bradford S. Jones. 2004. Event History Modeling: A Guide for Social Scientists. Cambridge: Cambridge University Press.

CPC (Centre for Productivity and Prosperity). 2012. Productivity and Prosperity in Quebec - 2012 Overview. Montreal: HEC Montréal.

Chenard, Pierre and Pierre Doray. 2013. "L'accessibilité aux études supérieures. Quelles démocratisations? [Accessibility to Higher Education: Which Democratisations (sic)?]" In L'accessibilité aux études supérieures, un projet inachevé [Accessibility to Higher Education, an Unachieved Project], edited by Pierre Chenard, Pierre Doray, Edmond-Louis Dussault and Martin Ringuette, 179-198. Québec: Presses de l’Université du Québec.

Chiswick, Barry R. and Noyna DebBurman. 2004. "Educational Attainment: Analysis by Immigrant Generation". Economics of Education Review 23(4): 361-379.

Clark, Burton R. 1960. “The 'Cooling-out' Function in Higher Education”. American Journal of Sociology 65(6): 569-576.

Clark, Ian D., Greg Moras, Michael L. Skolnik and David Trick. 2009. Academic Transformation: The Forces Reshaping Higher Education in Ontario. Montreal: McGill-Queen’s University Press.

CSF (Commissariat aux services en français). 2012. L'état de l'éducation postsecondaire en langue française dans le Centre-Sud-Ouest de l'Ontario. Pas d'avenir sans accès [The State of French Language Postsecondary Education in Ontario Southwest Centre: No Future Without Access]. Toronto: Imprimeur de la Reine pour l'Ontario.

D’Amours, Yvan. 2010. “La scolarité des francophones et des anglophones, à travers les groupes d'âge, au Québec et en Ontario [The Education of French-speakers and English-speakers Across Age Groups in Quebec and Ontario]". Données sociodémographiques en bref 14(2): 1-5.

Dandurand, Pierre. 1986. "Rapports ethniques et champ universitaire [Ethnic Relations and the Academic Field]". Recherches sociographiques 27(1): 41-77.

Dandurand, Pierre. 1991. "Mouvements de la scolarisation, conditions de vie et politiques d'accessibilité à l'université [Education Movements, Living Conditions, and University Accessibility Policies]". Revue des sciences de l'éducation 17(3): 437-463. 
Dandurand, Pierre, Marcel Fournier and Léon Bernier. 1980. "Développement de l'enseignement supérieur, classes sociales et luttes nationales au Québec [Higher Education Development, Social Classes, and National Struggles in Quebec]". Sociologie et sociétés 12(1): 101-132.

Descarries, Francine. 1980. L'école rose et les cols roses. La reproduction de la division sociale des sexes [Pink School and Pink Collars: Reproduction and the Social Division of Genders]. Montréal: Éditions coopératives A. Saint-Martin.

Dumais, Susan A. 2002. "Cultural Capital, Gender, and School Success: The Role of Habitus”. Sociology of Education 75(1): 44-68.

Finnie, Ross and Richard E. Mueller. 2010. “They Came, They Saw, They Enrolled: Access to Postsecondary Education by the Children of Canadian Immigrants." In Pursuing Higher Education in Canada: Economic, Social and Policy Dimension, edited by Ross Finnie, Marc Frenette, Richard E. Mueller and Arthur Sweetman, 191-216. Montreal: McGill-Queen’s University Press.

Jones, Glen A. 1997. Higher Education in Canada: Different Systems, Different Perspectives. New York: Routledge.

Kish, Leslie. 1995. Survey Sampling. New York: John Wiley and Sons.

Lahaye, Jacques. 1989. Données statistiques sur la population étudiante [Statistical Data on the School Population]. Quebec City: Ministère de l'Enseignement supérieur et de la Science.

Lahire, Bernard. 1998. L’homme pluriel. Les ressorts de l'action [The Plural Actor]. Paris: Nathan.

Lahire, Bernard. 2002. Portraits sociologiques. Dispositions et variations individuelles [Sociological Portraits: Dispositions and Individual Variations]. Paris: Nathan.

Laplante, Benoît, Patrick Sabourin and Alain Bélanger. 2010. Niveau de participation aux études supérieures. Les Francophones du Québec ne sont pas anormaux [Participation Level in Higher Education: Quebec French-speakers are not Anomalous]. Montreal: IRFA.

Monahan Edward, J. 2004. Collective Autonomy: A History of the Council of Ontario Universities, 1962-2000. Waterloo, ON: Wilfred Laurier University Press.

Perreault, Mathieu. 2012a. "Diplômés universitaires. Le Québec en retard malgré le gel [University Graduates: Quebec is Lagging Despite the Freeze]". La Presse, March 31. http://www.lapresse.ca/actualites/201203/31/01-4511307-diplomes-universitaires-le-quebec-enretard-malgre-le-gel.php 
Perreault, Mathieu. 2012b. “L'accès à l'université progresse plus rapidement en Ontario qu'au Québec [University Access Increases Faster in Ontario than in Quebec]". La Presse, May 8, A8.

Reay, Diane. 1998. “'Always Knowing’ and 'Never Being Sure:' Familial and Institutional Habituses and Higher Education Choice". Journal of Education Policy 13(4): 519-529.

Smyth, Emer and Joanne Banks. 2012. “'There was Never Really Any Question of Anything Else:' Young People's Agency, Institutional Habitus and the Transition to Higher Education". British Journal of Sociology of Education 33(2): 263-281.

Terrail, Jean-Pierre. 1990. Destins ouvriers. La fin d'une classe? [Working-class Destinies. The End of a Class?]. Paris: Presses Universitaires de France.

VSC (Vision 2000 Steering Committee). 1990. Vision 2000: Quality and Opportunity. Toronto: Ontario Ministry of Colleges and Universities.

Willis, Paul. 1979. Learning to Labour. Farnborough: Saxon House.

Zéroulou, Zaihia. 1988. “La réussite scolaire des enfants d'immigrés. L'apport d'une approche en termes de mobilisation [Immigrant Children's School Success: Contribution of the Mobilisation Approach]". Revue française de sociologie 29(3): 447-470. 
Table 1 Proportion holding a university degree by language and birth cohort. Population residing in the province. Quebec and Ontario. 2001 Census of Canada. Public use microdata file. Weighted estimation.

\begin{tabular}{lcccccc}
\hline \multicolumn{7}{c}{ Birth cohort } \\
& $1927-1936$ & $1937-1946$ & $1947-1956$ & $1957-1966$ & $1967-1976$ & All \\
\hline Quebec & 0.059 & 0.112 & 0.146 & 0.160 & 0.225 & 0.149 \\
$\begin{array}{l}\text { French } \\
\text { English }\end{array}$ & 0.152 & 0.211 & 0.267 & 0.243 & 0.323 & 0.248 \\
Other & 0.081 & 0.172 & 0.239 & 0.264 & 0.305 & 0.233 \\
Ontario & & & & & & \\
French & 0.066 & 0.112 & 0.165 & 0.175 & 0.267 & 0.164 \\
English & 0.102 & 0.155 & 0.201 & 0.191 & 0.258 & 0.194 \\
Other & 0.080 & 0.154 & 0.253 & 0.307 & 0.363 & 0.253 \\
\hline
\end{tabular}


Table 2 Proportion holding a university degree by language and birth cohort. People born in the province of residence from parents born in Canada. Quebec and Ontario. 2001 Census of Canada. Public use microdata file. Weighted estimation.

\begin{tabular}{lcccccc}
\hline \multicolumn{5}{c}{ Birth cohort } \\
& $1927-1936$ & $1937-1946$ & $1947-1956$ & $1957-1966$ & $1967-1976$ & All \\
\hline Quebec & 0.056 & 0.106 & 0.141 & 0.152 & 0.210 & 0.141 \\
$\begin{array}{l}\text { French } \\
\text { English }\end{array}$ & 0.099 & 0.123 & 0.221 & 0.189 & 0.253 & 0.191 \\
Other & 0.050 & 0.100 & 0.180 & 0.154 & 0.142 & 0.132 \\
Ontario & & & & & & \\
French & 0.056 & 0.084 & 0.123 & 0.104 & 0.188 & 0.116 \\
English & 0.086 & 0.132 & 0.176 & 0.157 & 0.212 & 0.165 \\
Other & 0.018 & 0.068 & 0.128 & 0.119 & 0.136 & 0.101 \\
\hline
\end{tabular}


Table 3 Proportion holding a university degree by language and birth cohort. Immigrants ("Foreign-born") and people born from two immigrant parents ("Two parents") residing in the province. Quebec and Ontario. 2001 Census of Canada. Public use microdata file. Weighted estimation.

\begin{tabular}{|c|c|c|c|c|c|c|}
\hline \multicolumn{7}{|c|}{ Birth cohort } \\
\hline & 1927-1936 & 1937-1946 & 1947-1956 & 1957-1966 & $1967-1976$ & All \\
\hline \multicolumn{7}{|l|}{ Quebec } \\
\hline \multicolumn{7}{|l|}{ French } \\
\hline Foreign-born & 0.158 & 0.293 & 0.313 & 0.332 & 0.456 & 0.331 \\
\hline Two parents & 0.067 & 0.167 & 0.341 & 0.273 & 0.424 & 0.333 \\
\hline \multicolumn{7}{|l|}{ English } \\
\hline Foreign-born & 0.217 & 0.304 & 0.313 & 0.256 & 0.347 & 0.290 \\
\hline Two parents & 0.141 & 0.322 & 0.372 & 0.341 & 0.392 & 0.312 \\
\hline \multicolumn{7}{|l|}{ Other } \\
\hline Foreign-born & 0.079 & 0.178 & 0.239 & 0.269 & 0.326 & 0.234 \\
\hline Two parents & 0.150 & 0.247 & 0.357 & 0.288 & 0.293 & 0.285 \\
\hline \multicolumn{7}{|l|}{ Ontario } \\
\hline \multicolumn{7}{|l|}{ French } \\
\hline Foreign-born & 0.155 & 0.377 & 0.448 & 0.409 & 0.432 & 0.392 \\
\hline Two parents & - & - & - & - & - & - \\
\hline \multicolumn{7}{|l|}{ English } \\
\hline Foreign-born & 0.127 & 0.181 & 0.215 & 0.222 & 0.289 & 0.210 \\
\hline Two parents & 0.090 & 0.139 & 0.221 & 0.210 & 0.306 & 0.223 \\
\hline \multicolumn{7}{|l|}{ Other } \\
\hline Foreign-born & 0.079 & 0.152 & 0.249 & 0.313 & 0.372 & 0.249 \\
\hline Two parents & 0.100 & 0.241 & 0.326 & 0.277 & 0.343 & 0.298 \\
\hline
\end{tabular}


Effects of cohort, social origin and immigration on university enrolment. Cox proportional hazards model. Coefficients expressed as hazard ratios. Data from cycles 10, 15, 20 and 25 of the Canadian General Social Survey. Weighted estimation. Standard errors deflated using average design effects.

\begin{tabular}{|c|c|c|c|c|c|c|c|c|c|c|c|c|}
\hline & \multicolumn{2}{|c|}{$\begin{array}{c}\text { Quebec } \\
\text { French-speaking }\end{array}$} & \multicolumn{2}{|c|}{$\begin{array}{c}\text { Quebec } \\
\text { English-speaking }\end{array}$} & \multicolumn{2}{|c|}{$\begin{array}{c}\text { Quebec } \\
\text { Immigration }\end{array}$} & \multicolumn{2}{|c|}{$\begin{array}{c}\text { Ontario } \\
\text { English-speaking }\end{array}$} & \multicolumn{2}{|c|}{$\begin{array}{c}\text { Ontario } \\
\text { French-speaking }\end{array}$} & \multicolumn{2}{|c|}{$\begin{array}{c}\text { Ontario } \\
\text { Immigration }\end{array}$} \\
\hline & Gross & Net & Gross & $\mathrm{Net}$ & Gross & Net & Gross & Net & Gross & Net & Gross & Net \\
\hline \multicolumn{13}{|l|}{ Cohort [1975-1990] } \\
\hline Before 1936 & $0.202^{* * *}$ & $0.349^{* * *}$ & $0.132^{* *}$ & $0.180^{* *}$ & $0.282^{* * *}$ & $0.588^{*}$ & $0.371^{* * *}$ & $0.616^{* * *}$ & $0.265^{* *}$ & 0.458 & $0.157^{* * *}$ & \\
\hline $1936-1950$ & $0.530^{* * *}$ & 0.908 & 0.641 & 0.885 & $0.621^{*}$ & 1.326 & $0.599^{* * *}$ & 0.935 & $0.223^{* * *}$ & $0.431^{*}$ & $0.378^{* * *}$ & \\
\hline $1951-1974$ & $0.685^{* * *}$ & 0.993 & 0.902 & 1.003 & 0.882 & $1.339^{*}$ & $0.613^{* * *}$ & $0.817^{* *}$ & $0.519^{* *}$ & 0.785 & $0.534^{* * *}$ & \\
\hline \multicolumn{13}{|l|}{ Social origin [No PSE $\rceil$} \\
\hline Non universitv PSE & $2.348^{* * *}$ & $2.174^{* * *}$ & $2.061^{*}$ & $1.813^{*}$ & $2.266^{* * *}$ & $2.361^{* * *}$ & $1.775^{* * *}$ & $1.689^{* * *}$ & $2.584^{* * *}$ & $2.208^{* *}$ & $1.863^{* * *}$ & \\
\hline University & $4.766^{* * *}$ & $4.361^{* * *}$ & $3.069^{* * *}$ & $2.689^{* * *}$ & $4.078^{* * *}$ & $4.089^{* * *}$ & $5.429^{* * *}$ & $5.197^{* * *}$ & $5.553^{* * *}$ & $4.407^{* * *}$ & $4.253^{* * *}$ & \\
\hline \multicolumn{13}{|c|}{ Immigration [Foreign-born father or mother] } \\
\hline Foreign-born father and mother & & & & & $1.656^{* * *}$ & $1.732^{* * *}$ & & & & & 1.056 & $1.137^{*}$ \\
\hline Landed before age 15 & & & & & $1.516^{* *}$ & 1.250 & & & & & $1.284^{* * *}$ & 1.107 \\
\hline Landed at age 15 or later & & & & & 1.312 & 1.210 & & & & & 0.0953 & 0.883 \\
\hline \multicolumn{13}{|c|}{ Cohort and social origin $\lceil 1975-1990$, no PSE $\rceil$} \\
\hline Before 1936, no PSE & & & & & & & & & & & & $0.171^{* * *}$ \\
\hline Before 1936, non universitvPSE & & & & & & & & & & & & $0.404^{* *}$ \\
\hline Before 1936, university & & & & & & & & & & & & 1.149 \\
\hline 1936-1950, no PSE & & & & & & & & & & & & $0.429^{* * *}$ \\
\hline 1936-1950. non universitvPSE & & & & & & & & & & & & 0.861 \\
\hline 1936-1950, university & & & & & & & & & & & & $1.632^{* *}$ \\
\hline 1951-1974. no PSE & & & & & & & & & & & & $0.525^{* * *}$ \\
\hline 1951-1974. non universitvPSE & & & & & & & & & & & & $0.804^{*}$ \\
\hline 1951-1974, university & & & & & & & & & & & & $1.950^{* * *}$ \\
\hline 1975-1990. non universitvPSE & & & & & & & & & & & & 1.114 \\
\hline 1975-1990, universitv & & & & & & & & & & & & $2.331^{* * *}$ \\
\hline
\end{tabular}

Social origin: "no PSE": neither father nor mother has more than a secondary diploma; "non-university PSE": father or mother has a postsecondary diploma, but neither has a university diploma; "university": father, mother or both have a university diploma.

${ }^{*} p<0.05 ;{ }^{* *} p<0.01 ;{ }^{* * *} p<0.001$. The reference modality of each variable is given between brackets. 


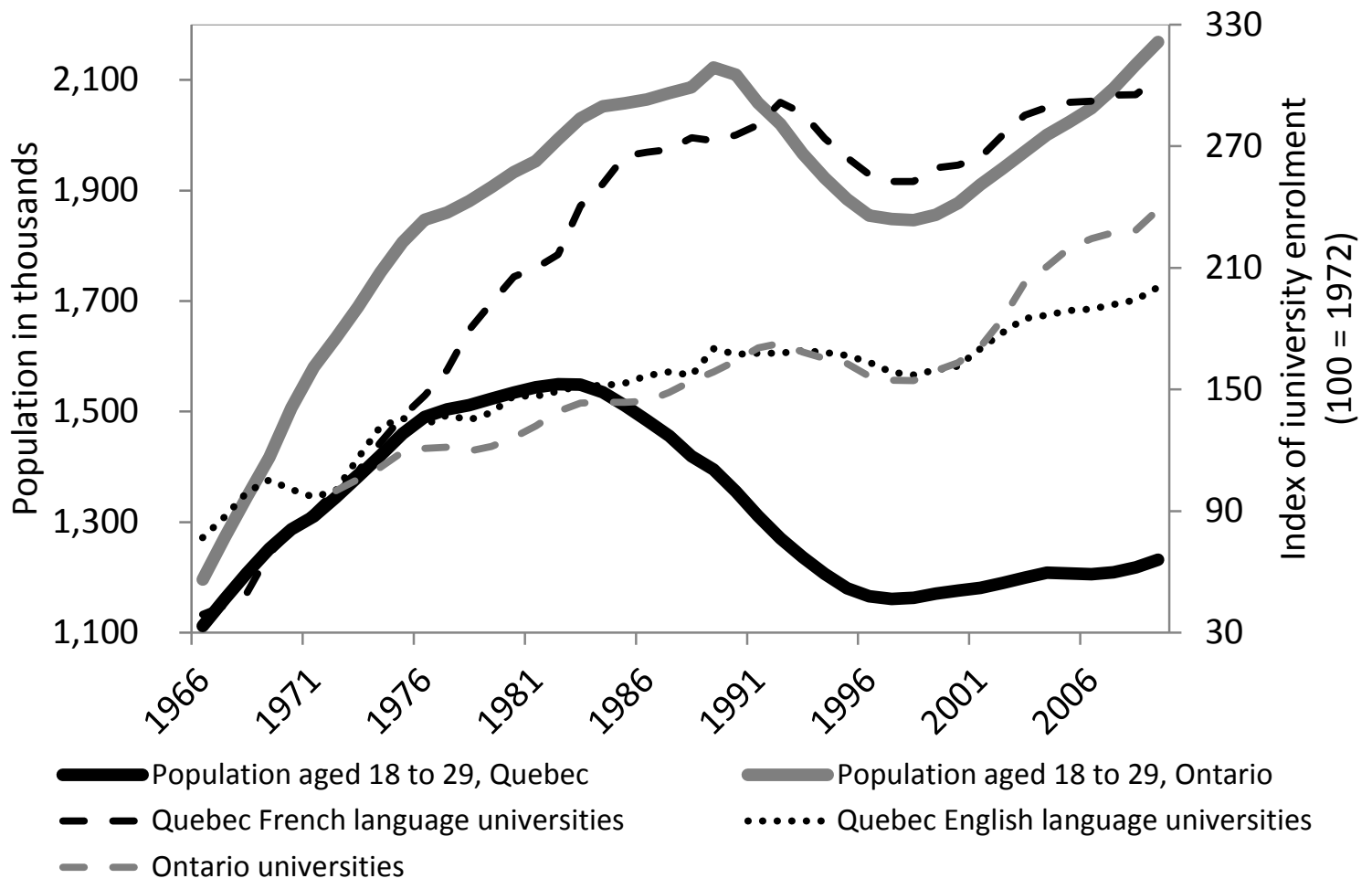

Figure 1: Population aged 18 to 29 by province in thousands, 1966 to 2009 . Index of university enrolment, 100 in 1972, Quebec (1966 to 2009) and Ontario (1972 to 2009).

Sources: Lahaye (1989); Ministère de l'Éducation, du Loisir et du Sport du Québec, Statistiques sur l'éducation 2003-2008; Association of Universities and Colleges of Canada, University enrolment in Ontario by registration status, program level, 1972-2009; Statistics Canada, Estimates of population, by age group and sex, Canada, provinces and territories, annual (Persons), 1921 to 1971 (CANSIM table 051-0026); Estimates of population, by age group and sex for July 1, Canada, provinces and territories, annual (Persons), 1971 to 2012, CANSIM table 051-0001. 


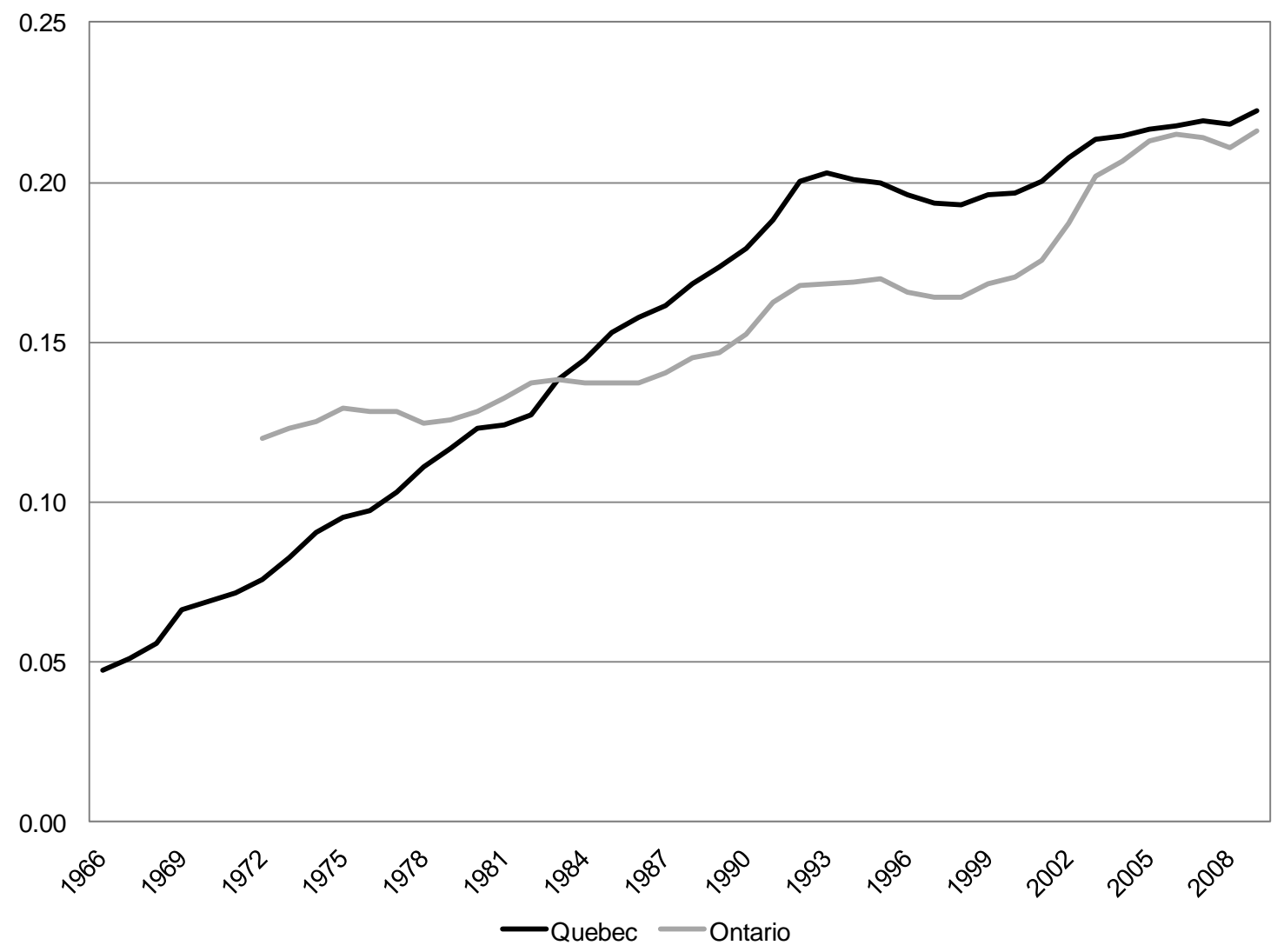

Figure 2: Ratio of university enrolment to population aged 18 to 29 by province, Quebec (1966 to 2009) and Ontario (1972 to 2009).

Sources: Lahaye (1989); Ministère de l'Éducation, du Loisir et du Sport du Québec, Statistiques sur l'éducation 2003-2008; Association of Universities and Colleges of Canada, University enrolment in Ontario by registration status, program level, 1972-2009; Statistics Canada, Estimates of population, by age group and sex, Canada, provinces and territories, annual (Persons), 1921 to 1971 (CANSIM table 051-0026); Estimates of population, by age group and sex for July 1, Canada, provinces and territories, annual (Persons), 1971 to 2012, CANSIM table 051-0001. 

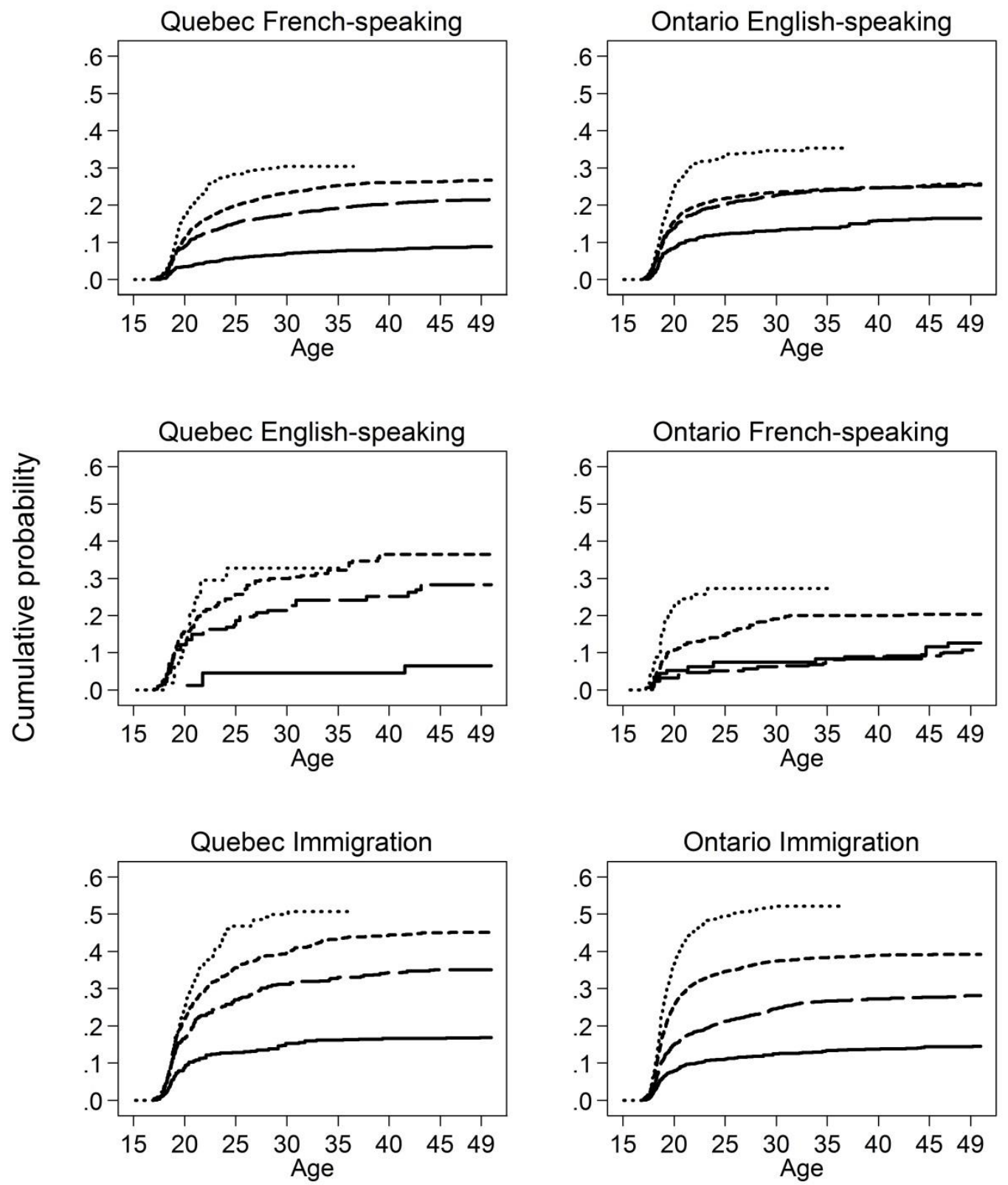

Before 1936

1936 to 1950

1951 to 1974

1975 to 1990

Figure 3.Cumulative probability over age of enrolment in university by birth cohort and socio-linguistic group. Product-limit estimator of the survivor function. Source: Statistics Canada, cycles 10, 15, 20 and 25 of the General Social Survey. 